\title{
Types and Actions of Chemicals for Weed Control
}

\author{
by Keith F. Best, Swift Current
}

Over the past ten or fifteen years the chemical seed control industry has flourished and millions of dollars are spent annually on applications of various compounds to our fields, orchards and gardens. To keep abreast of all the new products being made available would be a full time job in itself. A summary of the kinds and actions of herbicides might be of some interest.

All herbicides sold in Canada must, under the Pest Control Products'Act, be registered annually. The Act is administered by the Plant Products Division, Department of Agriculture, Ottawa. During 1956 there were 76 companies offering one or more chemical herbicides for sale in Canada. The number of weed killers registered was 350. In 1960 there were 87 companies registering 478 weed killers for the Canadian market. These chemicals may be classified in three main groups: the contact herbicides, the selective or systemic herbicides, and the soil sterilants.

\section{Contact Herbicides}

During the latter part of the nineteenth century, agricultural scientists found that some of the common chemicals could be used to kill weeds in the grain fields with a certain margin of safety to the crops. These belonged to the inorganic or mineral group and their action was to burn, corrode or poison plant tissue. They killed only those portions of the plants which they came in direct contact with and thus they became known as contact herbicides. They may cause severe damage to crops if the rates of application are too heavy.

Contact herbicides shrivel the proteins in the cells. There is practically no movement of the chemical away from the treated area. Chlorophyll is destroyed and if the spray pattern is poor, blotching of the leaves will result. Under favorable conditions the tops of affected plants show a rapid browning and crisping. Perennials will grow again from the roots. If annuals are not killed quickly they also survive and resume their growth. This is why limited crop damage after spraying with contact sprays may not have any lasting effects.

\section{Selective or Systemic Herbicides}

A selective herbicide is a chemical compound that is more toxic to one plant than to another. A systemic herbicide is a toxic substance which moves or is translocated within a plant.

Around the beginning of the present century, a worker, noting the large galls resulting from insect punctures on plants, concluded that something must have been added in the puncture to alter the cell structure in the area. The idea was born that formative functions of plants are controlled by specific substances, hormones, circulating in their tissues.

Hormone was first isolated from pollen grains in 1910. Since that time many hormones have been studied. Prior to 1942 all of the hormone work involved the promoting and regulating of growth in plants with usually beneficial results. With the finding of 2,4-D acid in some of the hormones two years of private investigations were undertaken and in 1944 the new wonder weed killer was officially born, the first hormone or systemic herbicide.

The selective herbicides contain many other compounds besides 2,4-D and each one possesses a somewhat different mode of action. They all injure and finally kill susceptible plants by causing the distortion of tissues. If a chemical translocates well then a little bit goes a long way and a low volume spray can be used.

The translocated herbicides are most effective on the new, actively growing parts ofl the plants. Foliage treatments should be done when annual weeds are tender. Perennial weeds are often more sensitive at the time of flowering when their root reserves are low and they have more difficulty in producing new shoots to replace the damaged ones. Although not a complete control, sel- 
ective sprays will usually retard growth of perennial weeds in crops and prevent the formation of seed.

Variations in plant structure influence the penetration of selective killers when they are applied as a foliage spray. Many leaves have a waxy covering on the upper surface and, as water is shed from a duck, any solution tends to run off unless a wetting or sticking agent is added. Deflecting leaf hairs, relatively few pores on the upper surface of the leaves, and corky layers greatly hinder the penetration of sprays. Where leaves arise sharply from the stem, as in cereals, the solutions run off too quickly for good penetration. Since roots do not have the waxy cuticle they can absorb the chemical even when it has not been emulsified.

The chemical 2,4-D comes in three basic formulations, esters, amines, and sodium salts. Of these the esters are generally the strongest. They must be dissolved in oil and must be either emulsified in water with the aid of a stabilizing emulsifying agent for ground sprays or be mixed with diesel oil for aircraft applications. The esters are more toxic because they are more volatile, which allows them to get into the plant through its pores, and to spread to other areas that might have been missed by the spray. Low volatile esters are made with heavier alcohols and they are better where sprayings must be done near sensitive plants.

Translocated herbicides work slowly, particularly during cool, dry weather. Plant enzymes of susceptible plants may change the chemical to poison or the herbicide may stop or alter some step in the plant metabolism. The heredity mechanism may also be upset. Affected cells either stop dividing to make new growth and stunting results, or they divide too fast causing twisting and bending. When the chemical in the plant becomes weaker, it often causes the plant to send out roots in unusual places. Uneven growth may split the stem and microorganisms can readily gain entry and decomposition sets in. Amino triazole induces starvation in the plant by destroying the chlorophyll. Some or all of these symptoms may be produced by 2,4-D and its relatives.

One of the most difficult problems is the treating of annual weeds in annual crops through soil applications for selective control. This becomes necessary where we have annual weeds that cannot be sprayed in the growing crop lest damage result. Here the chemicals are applied before the weeds or the crop come up. This pre-emergence treatment is intended to kill the germinating weed seeds without harming the sprouting crop. The effects may last long enough to kill weeds which germinate after the crop is up. The important factors with this type of control are adequate moisture and the proper placing of the chemical. Too much moisture may leach the chemical out of the soil while too little may permit the weeds to get a good start from their place in moister soil below. At present there is a narrow safety margin in selective soil treatments between the amount required to do a proper job on the weeds and the amount that is safe for the crop.

\section{Soil Sterilants}

The third main group of chemicals is classed as soil sterilants. During the last war a native from one of the islands of the South Pacific, when asked if the Americans were better jungle fighters than the Japanese, replied that the Americans just removed the jungles. That is what happens with the soil sterilants, they remove all plants. However, some of the long-term soil sterilants like sodium chlorate, the borates, and monuron (CMU) show a certain degree of selectivity at lower rates for some annuals and perennials. Under certain conditions some eliminate the grasses while leaving the broad-leaved plants, others remove the forbs and spare the grasses.

The effectiveness of these chemicals may be influenced by type of soil and rainfall so that retreatment may be necessary. Applications for the control of perennial weeds are usually made in the fall, treatments for annual weeds are usually made in the spring. Dead growth and all plants over eight inches in height should be removed before treatment so that the chemicals can enter the soil rapidly. Soil sterilants may kill trees and shrubs if their roots extend under the treated area and thus come in contact with the herbicide as it penetrates the soil. 